\title{
EEF1G wt Allele
}

National Cancer Institute

\section{Source}

National Cancer Institute. EEF1G wt Allele. NCI Thesaurus. Code C52031.

Human EEF1G wild-type allele is located in the vicinity of 11 q12.3 and is approximately 14 $\mathrm{kb}$ in length. This allele, which encodes elong ation factor 1-gamma protein, plays a putative role in the assembly of multi-subunit complexes during translation. The EEF1G gene is overexpressed in certain types of cancer such as colorectal carcinoma and hepatocellular carcinoma. 